\title{
A report on XXIX Annual Conference of Indian Association for Angiosperm Taxonomy and National Symposium on 'Modern Trends in Biosystematics of Angiosperms'
}

The XXIX Annual Conference of Indian Association for Angiosperm Taxonomy and National Symposium on 'Modern Trends in Biosystematics of Angiosperms' was held during $11-13^{\text {th }}$ November, 2019 at Jawaharlal Nehru Tropical Botanic Garden \& Research Institute, Palode, Thiruvananthapuram jointly with the support from Birbal Sahni Institute for Palaeosciences, Lucknow, UP. There were 242 delegates from 14 states, representing various institutions/organizations.

The Inaugural function was presided over by Prof. Alka Chaturvedi, President of IAAT in which Dr. A. Mao, Director, Botanical Survey of India inaugurated the conference. Prof. M. Sanjappa released the abstract book of the conference and Prof. Balakrishna Pisupati, released the news letter of JNTBGRI, 'Gardenia'. Prof. S.R. Yadav, Vice President of IAAT gave felicitation. Dr. C. Livingstone and Prof. Pushpa Patel the senior members of IAAT as well as Prof. Vinay M. Raole, the Organizing Secretary of $28^{\text {th }}$ Annual Conference of IAAT were honored.

Prof. Vatsavaya S. Raju, Kakatiya University, Warangal, recipient of Prof. Y.D. Tiagi Gold Medal and Dr. Sudhansu Sekhar Dash, Botanical Survey of

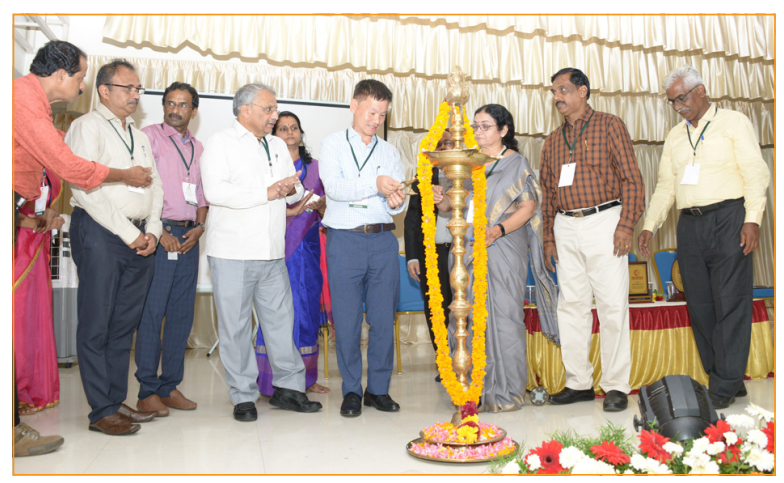

Lighting of the lamp during the inaugural ceremony by Dr. A. Mao, Director, Botanical Survey of India.
India, Kolkata, recipient of Prof. V.V.Sivarajan Gold Medal, delivered medal lectures. Prof. Kameswara Rao Endowment Lecture, "Ethical issues in plant taxonomy research", was presented by Dr. M. Sanjappa (former Director, Botanical Survey of

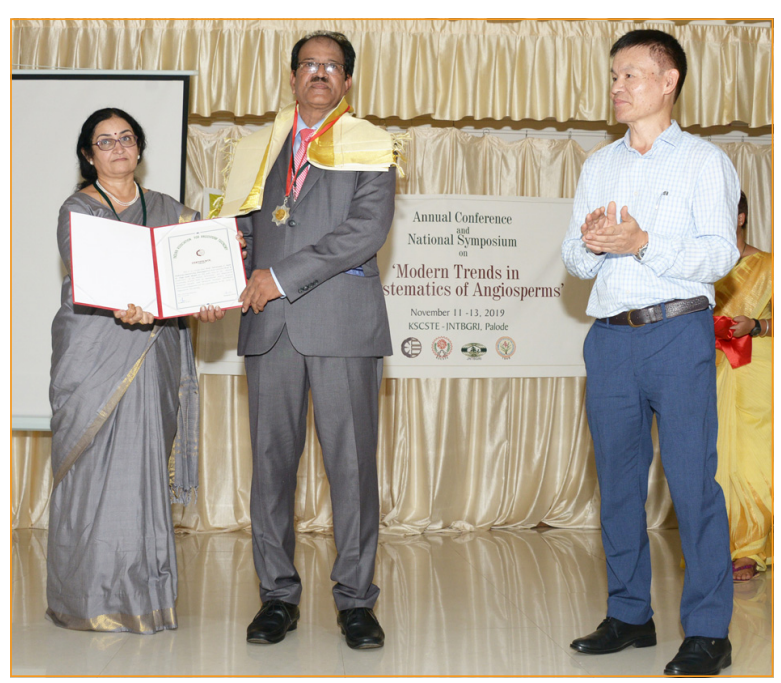

Prof. Vatsavaya S. Raju, Kakatiya University, Warangal receiving Prof. Y. D. Tiagi Gold Medal from Prof. Alka Chaturvedi, President, IAAT.

India), GKVK, Bengaluru. Dr. Vandana Prasad, Director, BSIP, Lucknow, offered Dr. P.K.K. Nair Memorial Lecture "Fossil pollen: A reliable tool for tracing the evolutionary history of Angiosperms". There was a special theme lecture, "Palaeobotany on Angiosperm Taxonomy in Indian context," by Suresh Kumar Pillai S., BSIP, Lucknow.

The deliberations under 7 sessions were on biosystematics, conservation of angiosperms, ethnobotany, floristics, modern trends in taxonomy etc. During the technical sessions conducted in four venues, 94 research papers were presented for contests. For the poster session there were 46 presentations. The winners of various contests were: 


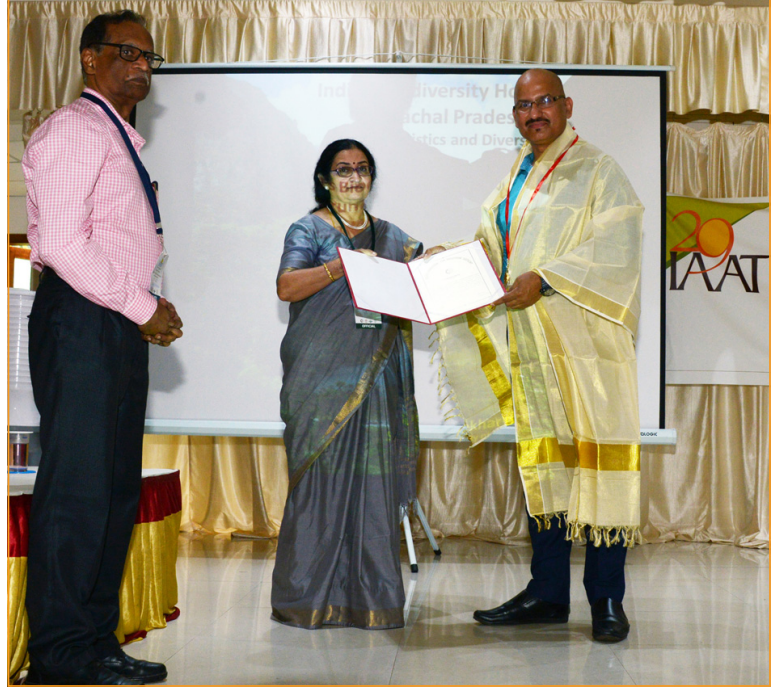

Dr. Sudhansu Sekhar Dash, Botanical Survey of India, Kolkata receiving Prof. V.V. Sivarajan Gold Medal from Prof. Alka Chaturvedi, President, IAAT.

Prof. Rolla S. Rao Award - Anto Mathew, JNTBGRI, Palode

Prof. K.S. Manilal Award - Shinoj K., University of Calicut

Prof. S.R. Yadav Award - Hareesh V.S., University of Calicut

Fr. Anthony Mukkath - K.S. Manilal Award Ashwini M. Darshetkar, Agarkar Research Institute, Pune

Prof. M. Sabu Award - Senthilkumar Umapathy, SRM Institute of Science and Technology, Kanchipuram

Prof. T.R. Sahu Award was not considered since there was only one contestant.

A special session for research scholars on 'Scientific writing' was conducted on $13^{\text {th }}$ November 2019

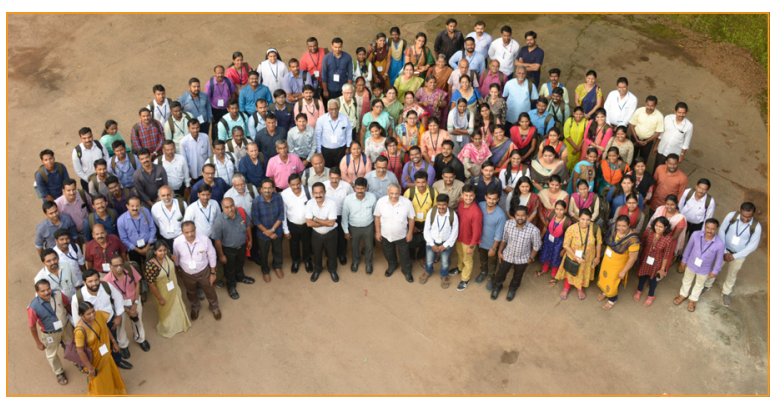

Delegates of $29^{\text {th }}$ IAAT Conference

where Prof. M. K. Janarthanam was the resource person. There was also a students taxonomy interactive corner in which Dr. C. Sathishkumar and Prof. D. Narasimhan were the resource persons. Fifty eight PG (Botany) students and teachers from 4 colleges participated.

A 'Taxo-Expo' was also organized in the campus, where the angiosperm novelties as well as special generic collections from JNTBGRI were projected.

The valedictory function on $13^{\text {th }}$ November 2019 was presided over by Dr. Alka Chaturvedi. The awards were declared by Dr. M. Sabu, Secretary, IAAT. Mr. P.K. Kesavan IFS, PCCF and Head of Forests, Kerala, the Chief Guest of the day distributed the awards and offered the valedictory address. The participants unanimously acknowledged and appreciated the excellent organization of the conference. Venue of the $30^{\text {th }}$ IAAT conference was declared as Karnataka Science College, Dharwad. The meeting ended with the vote of thanks by Dr. Mathew Dan, Organizing Secretary.

\section{Dr. R. Prakashkumar \\ Chairman \\ Organizing Committee}

